\title{
IDENTIFIKASI PEMBEKALAN KETERAMPILAN ABAD 21 PADA ASPEK KETERAMPILAN PEMECAHAN MASALAH SISWA SMA KOTA BENGKULU DALAM MATA PELAJARAN FISIKA
}

\author{
Agung Jayadi*, Desy Hanisa Putri, Henny Johan \\ Program Studi Pendidikan Fisika, Fakultas Keguruan dan Ilmu Pendidikan, Universitas Bengkulu, \\ Jl. W.R Supratman Kandang Limun, Bengkulu \\ E-mail*: agungjayadi464@gmail.com
}

\begin{tabular}{l|l|l|l}
\hline Diterima 11 November 2019 & Direvisi 8 April 2020 & Disetujui 22 April 2020 & Dipublikasikan 29 April 2020
\end{tabular}

https://doi.org/10.33369/jkf.3.1.25-32

\begin{abstract}
ABSTRAK
Tujuan dari penelitian ini adalah untuk mendeskripsikan hasil indentifikasi pembekalan keterampilan abad 21 pada aspek keterampilan pemecahan masalah siswa dalam mata pelajaran fisika menurut persepsi guru dan siswa serta mendeskripsikan keterampilan pemecahan masalah siswa SMA Kota Bengkulu. Jenis yang penelitian ini adalah Descriptive Research. Sampel penelitian ini berjumlah 300 siswa dari 3 SMA yang berbeda di Kota Bengkulu dan 7 orang guru. Instrumen pengumpulan data yang digunakan dalam penelitian ini adalah angket persepsi siswa terhadap pembekalan, persepsi guru terhadap pembekalan, dan persepsi siswa terhadap penguasaan keterampilan abad 21 pada aspek keterampilan pemecahan masalah siswa. Berdasarkan analisis data, pembekalan aspek keterampilan pemecahan masalah yang telah dilakukan guru SMAN Kota Bengkulu dalam pembelajaran fisika berada pada kategori baik menurut persepsi guru dan siswa. Aspek keterampilan pemecahan masalah siswa dalam mata pelajaran fisika, yang dimiliki siswa SMAN Kota Bengkulu berada pada kategori baik menurut persepsi siswa. Hasil yang diperoleh dapat dijadikan sebagai need assessment bagi penelitian RND (Reasearch And Development) seperti pengembangan media pembelajaran, modul pembelajaran dan model pembelajaran.
\end{abstract}

Kata Kunci: pembekalan, keterampilan abad 21, keterampilan pemecahan masalah, pelajaran fisika, descriptive research

\begin{abstract}
This research was aimed to describe identifying results of debriefing of $21^{\text {st }}$ century skills in aspects of problem solving skills in physics subjects from teacher and student's perception and problem solving skills of public high school student in Bengkulu city. The type of this research was Descriptive Research. The research samples was 300 students from 3 high schools and 7 teachers. Data collection techniques used in this study were questionnaires for teachers and students. Based on data analysis, debriefing of $21^{\text {st }}$ century skills on aspects of problem solving skills of Bengkulu city high school students in physics subjects was in good category from teacher and student perception. Besides that, problem solving skills of Bengkulu city high school students in physics subjects was in good category from student perception. The obtained results can be used as a need assessment for RND (Research and Development) research such as the development of learning media and development of learning modules.
\end{abstract}

Keywords: debriefing, $21^{\text {st }}$ century skills, problem solving skills, physics subjects, descriptive research

\section{PENDAHULUAN}

Pendidikan merupakan kebutuhan manusia yang sangat penting karena pendidikan mempunyai tugas untuk menyiapkan SDM bagi pembangunan bangsa, pendidikan saat ini diharapkan dapat mengasilkan sumber daya pemikir yang mampu ikut membangun tatanan sosial dan pengetahuan sebagaimana layaknya warga dunia yang dihasikan oleh lembaga-lembaga yang dikelola secara profesional sehingga membuahkan hasil unggulan. Kemajuan teknologi informasi dan komunikasi telah mempengaruhi gaya hidup manusia dalam bekerja dan bersosialisasi. Memasuki abad 21, kemajuan teknologi telah menyentuh semua bidang termasuk pendidikan. 
Abad 21 ditandai sebagai keterbukaan atau abad globalisasi, artinya kehidupan manusia pada abad ke-21 mengalami perubahan-perubahan yang fundamental yang berbeda dengan tata kehidupan dalam abad sebelumnya. Dengan sendirinya abad ke-21 meminta sumberdaya manusia yang berkualitas, yang dihasikan oleh lembaga-lembaga yang dikelola secara profesional sehingga membuahkan hasil unggulan. Tuntutan-tuntutan yang serba baru tersebut meminta berbagai terobosan berpikir, penyusun konsep, dan tindakan-tindakan [1].

Pendidikan pada abad 21 menuntut berbagai keterampilan yang harus dikuasai seseorang, sehingga diharapkan pendidikan dapat mempersiapkan siswa untuk menguasai berbagai keterampilan tersebut agar menjadi pribadi yang sukses dalam hidup. Keterampilan-keterampilan penting di abad ke-21 masih relevan dengan 4 pilar kehidupan yang mencakup learning to know, learning to do, learning to be , dan learning to live together.

Pencapaian keterampilan abad 21 tersebut dilakukan dengan memperbaharui kualitas pembelajaran, membantu siswa mengembangkan partisipasi, menyesuaikan personalisasi belajar, menekankan pada pembelajaran berbasis proyek/masalah, mendorong kerjasama dan komunikasi, meningkatkan keterlibatan dan motivasi siswa, membudayakan kreativitas dan inovasi dalam belajar, menggunakan sarana belajar yang tepat, mendisain aktivitas belajar yang relevan dengan dunia nyata, memberdayakan metakognisi, dan eksplisit diajarkan. Secara singkat, pembelajaran abad ke-21 memiliki prinsip pokok bahwa peran masyarakat dan guru dalam melaksanakan pembelajaran abad ke-21 sangat penting untuk mewujudkan masa depan anak bangsa yang lebih baik.Oleh karenanya, sistem pendidikan harus diorientasikan pada pembekalan dan pengembangan keterampilan abad 21 siswa. Dalam $21^{\text {st }}$ Century Partnership Learning Framework, terdapat sejumlah keterampilan abad 21 yang harus dikembangkan pada siswa dalam pembelajaran masa kini, yaitu (1) keterampilan berpikir kritis dan memecahkan masalah (critical-thinking and problem skills) (2) keterampilan berkomunikasi dan bekerjasama (communication and collaboration skills) (3) keterampilan mencipta dan memperbaharui (creativity and innovation skills), (4) literasi teknologi informasi dan komunikasi (information and communications technology literacy), (5) keterampilan belajar kontekstual (contextual learning skills), dan (6) keterampilan informasi dan literasi media (information and media literacy skills) [2].

Pembelajaran fisika di sekolah memiliki peran sentral dalam membekalkan keterampilan abad 21 kepada siswa. Tujuan pembelajaran fisika yang tertuang di dalam konsep kurikulum 2013 ialah menguasi konsep dan prinsip fisika, memiliki keterampilan mengembangkan pengetahuan dan sikap percaya diri sebagai bekal untuk melanjutkan pendidikan, serta sebagai bekal untuk mencadangkan ilmu pengetahuan dan iptek [3]. Keterampilan abad 21 adalah keterampilan yang dibutuhkan kaum muda agar berhasil bersaing di abad 21. Setiap orang yang berpendidikan harus memiliki keterampilan inti dalam keaksaraan dan berhitung dan keterampilan yang memungkinkannya berpikir logis dan memecahkan masalah secara efektif dan mandiri. Ilustrasi sebuah pelangi dapat menggambarkan apa yang dibutuhkan siswa melalui mata pelajaran di sekolah yang dikombinasikan dengan keterampilan abad ke-21. Struktur dan komponen dari ilustrasi pelangi tersebut yaitu keterampilan, pengetahuan, dan keahlian yang perlu dikuasai siswa untuk bekerja dan hidup dengan sukses di abad ke-21 [4], dapat diihat pada gambar 1.

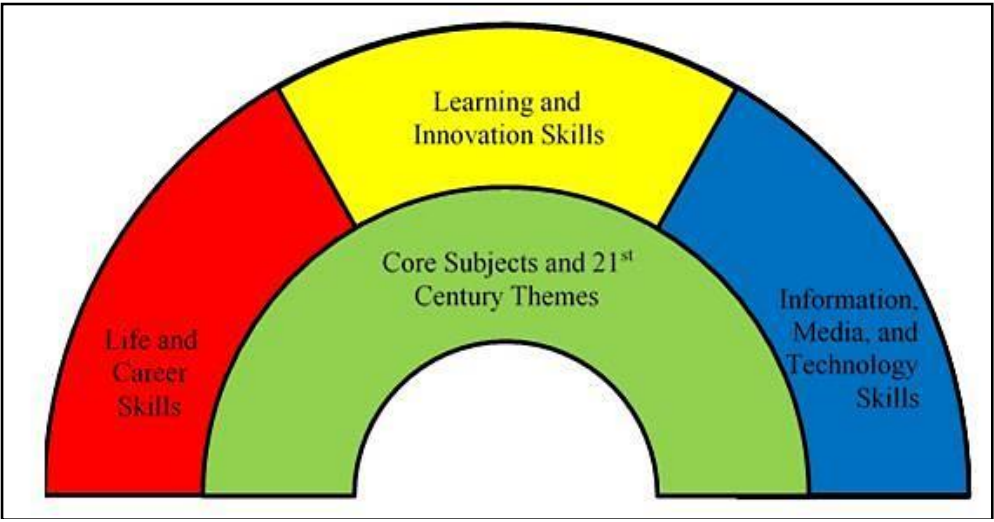

Gambar 1. Pelangi Pengetahuan dan Keterampilan Abad 21

Identifikasi Pembekalan Keterampilan Abad 21 pada Aspek Keterampilan Pemecahan Masalah Siswa SMA Kota Bengkulu dalam.... Agung Jayadi, Desy Hanisa Putri, Henny Johan 
Penelitian mengenai pembekalan keterampilan abad 21 telah diidentifikasi berdasarkan persepsi guru. Pembekalan tersebut dilihat selama pembelajaran praktikum yang dilakukan oleh 25 guru [5]. Sedangkan penelitian mengenai pembekalan keterampilan abad 21 pada aspek keterampilan memecahkan masalah belum dilakukan.

Keterampilan abad 21 pada aspek keterampilan memecahkan masalah merupakan fokus dalam pembelajaran fisika. Dalam pemecahan masalah dibutuhkan juga kemampuan berpikir kritis yang merupakan dasar untuk menyelesaikan masalah. Keterampilan memecahkan masalah mencakup keterampilan lain seperti identifikasi dan kemampuan untuk mencari, memilih, mengevaluasi mengorganisir, dan mempertimbangkan berbagai alternatif dan menafsirkan informasi [6].

Perlunya mengidentifikasi pembekalan keterampilan abad 21 pada aspek pemecahan masalah dan seberapa baik keterampilan pemecahan masalah siswa agar nantinya guru dapat meningkatkan keterampilan pemecahan masalah siswa melalui peningkatan kualitas pembelajaran. Adapun langkah-langkah pemecahan masalah yang diidentifikasi sebagai keterampilan pemecahan masalah adalah visualisasi permasalahan, mendeskripsikan permasalahan kedalam konsep fisika, merencanakan solusi, melaksanakan solusi, dan mengevaluasi solusi [7].

Berdasarkan uraian yang telah dipaparkan, maka dilakukan penelitian yang berjudul "Identifikasi Pembekalan Keterampilan Abad 21 pada Aspek Keterampilan Pemecahan masalah Siswa SMA Kota Bengkulu Pada Mata Pelajaran fisika". Adapun tujuan penelitian adalah sebagai berikut: (1) mendeskripsikan hasil identifikasi pembekalan keterampilan abad 21 pada aspek keterampilan pemecahan masalah yang telah diberikan pada siswa menurut persepsi guru SMA kota Bengkulu dalam mata pelajaran fisika, (2) mendeskripsikan hasil identifikasi pembekalan keterampilan abad 21 pada aspek keterampilan pemecahan masalah yang telah dilakukan guru menurut persepsi siswa SMA kota Bengkulu dalam mata pelajaran fisika, dan (3) Mendeskripsikan keterampilan abad 21 pada aspek keterampilan pemecahan masalah yang dimiliki siswa menurut persepsi siswa SMA kota Bengkulu dalam mata pelajaran fisika.

\section{METODE PENELITIAN}

Penelitian ini tergolong penelitian deskriptif (descriptive research) yaitu penelitian yang dilakukan untuk menggambarkan atau menjelaskan secara sistematis, faktual, dan akurat mengenai fakta dan sifat populasi tertentu [8]. Responden dalam penelitian ini adalah 300 siswa SMA yang berasal dari 3 SMA di Kota Bengkulu dan 7 orang guru fisika. Instrumen yang digunakan dalam penelitian ini berupa lembar angket siswa dan guru.

Analisis data dalam penelitian ini dilakukan pada saat pengumpulan data berlangsung dan setelah selesai pengumpulan dalam periode tertentu. Analisis data kualitatif dilakukan secara interaktif dan berlangsung secara terus menerus sampai tuntas sehingga datanya sudah jenuh. Aktivitas dalam analisis data, yaitu data reduction, data display, dan conclusion drawing/verification [8].

Analisis data angket menggunakan skala likert dengan memberikan skor pada masing-masing jawaban pertanyaan alternatif sebagai berikut:

Tabel 1. Alternatif Jawaban Dengan Skala Likert

\begin{tabular}{cc}
\hline Keterangan & Skala \\
\hline Sangat Setuju (SS) & 5 \\
Setuju (S) & 4 \\
Kurang Setuju (KS) & 3 \\
Tidak Setuju (TS) & 2 \\
Sangat Tidak Setuju (STS) & 1 \\
\hline
\end{tabular}

Setelah data angket telah terkumpul, kemudian dilakukan pengolahan data dan disajikan dalam bentuk tabel dan dianalisis. Pada penelitian ini, peneliti menggunakan analisis deskriptif yang dilakukan pengklasifikasian terhadap jumlah total skor responden. Dari jumlah skor jawaban responden yang diperoleh kemudian disusun kriteria penilaian untuk setiap item pernyataan.

Untuk menjawab deskripsi tentang masing-masing variabel penelitian, maka digunakan rentang kriteria penilaian sebagai berikut : 


$$
\mathrm{P}=\frac{\text { Rancangan }}{\text { Banyak Kelas }}
$$

$\mathrm{P}$ merupakan panjang kelas interval, rentang adalah data angket terbesar - data terkecil, dan banyak kelas adalah 3. Menetapkan peringkat dalam setiap variabel penelitian dapat dilihat dari perbandingan antara skor aktual dengan skor ideal, kecenderungan jawaban responden didasarkan pada nilai rata-rata skor jawaban yang selanjutnya dikategorikan pada rentang skor berikut ini: skor minimum adalah 1 dan skor maksimum adalah 5 , sedangkan lebar skala $=\frac{5-1}{3}=1,33$ dengan demikian kategori skala dilihat pada tabel 2.

Tabel 2. Kategori Skala

\begin{tabular}{cc}
\hline Skala & Kategori \\
\hline $1,00-2,33$ & Kurang \\
$2,34-3,66$ & Cukup \\
$3,67-5$ & Baik \\
\hline
\end{tabular}

Data angket dikategorikan berdasarkan tabel 2. Selanjutnya, dilakukan triangulasi pada data yang diperoleh yakni dianalisis secara deskriptif untuk mendapatkan informasi yang dibutuhkan.

\section{Hasil dan Pembahasan}

Penelitian dilakukan di tiga SMA Negeri kota Bengkulu yaitu SMA Negeri 5 Kota Bengkulu, SMA Negeri 7 Kota Bengkulu, dan SMA Negeri 9 Kota Bengkulu. Eksplorasi pembekalan siswa terhadap keterampilan abad 21 dilakukan dengan menggunakan lembar angket persepsi siswa dan guru, melibatkan 300 siswa MIPA SMA kelas X, XI, dan kelas XII sebagai responden yang berasal dari 3 SMA Negeri Kota Bengkulu dan 7 orang guru fisika.

Angket persepsi guru dan siswa terhadap pembekalan keterampilan abad 21 pada aspek pemecahan masalah terdiri atas 5 indikator yaitu $I_{1}$ (Memvisualisasi permasalahan), $I_{2}$ (Mendeskripsikan permasalahan), $\mathrm{I}_{3}$ (merencanakan solusi), $\mathrm{I}_{4}$ (melaksanakan rencana), dan $\mathrm{I}_{5}$ (mengevaluasi solusi) dengan jumlah butir angket sebanyak 12 (P1 sampai dengan P12).

\subsection{Angket Persepsi Siswa terhadap Pembekalan Keterampilan Pemecahan Masalah yang Dilakukan oleh Guru}

Angket ini merupakan angket yang ditujukan untuk siswa menyatakan pendapat apakah guru telah memberikan pembekalan keterampilan abad 21 pada aspek keterampilan pemecahan masalah. Berikut hasil angket persepsi siswa terhadap pembekalan keterampilan abad 21 pada aspek keterampilan pemecahan masalah.

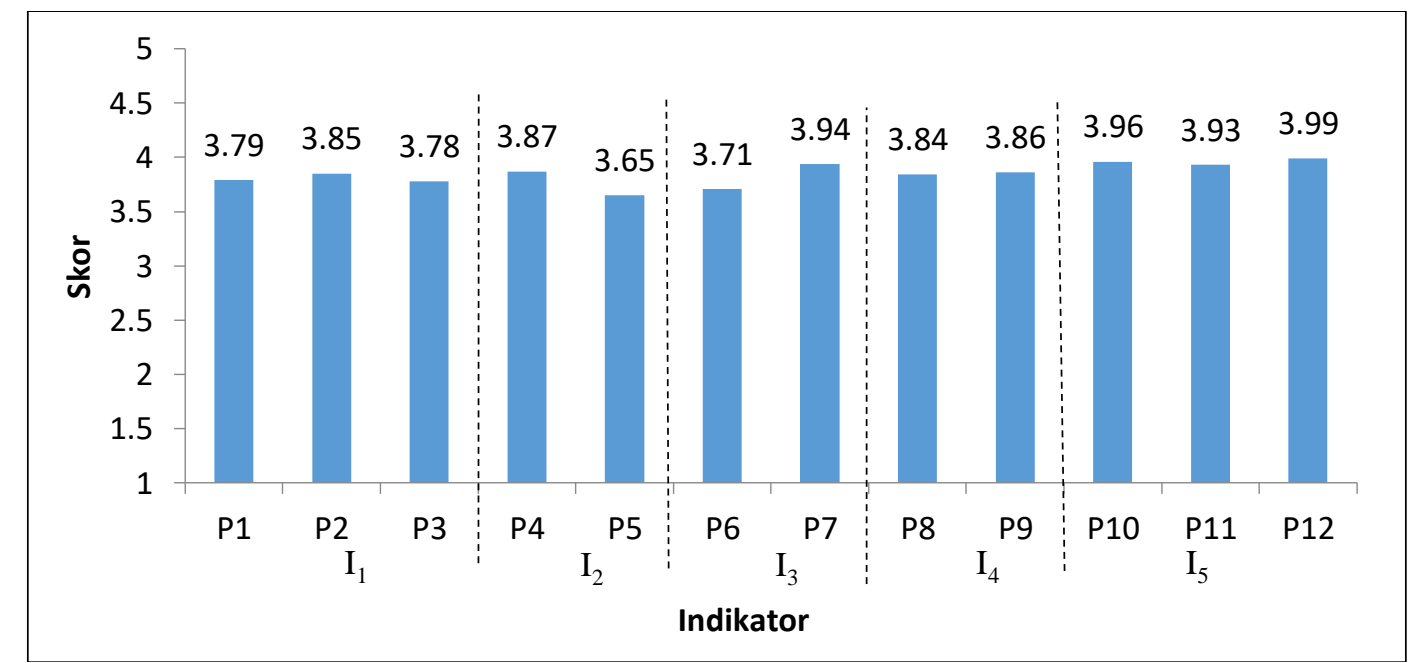

Gambar 2. Persepsi Siswa terhadap Pembekalan Keterampilan Pemecahan Masalah 
Berdasarkan gambar 2, hasil analisis data angket setiap butir dalam kategori Baik. Adapun skor rata-rata setiap indikator pembekalan keterampilan pemecahan masalah siswa dapat dilihat pada tabel 3.

Tabel 3. Persepsi siswa terhadap pembekalan keterampilan pemecahan masalah

\begin{tabular}{ccc}
\hline Indikator keterampilan & Skor rata-rata & Kategori \\
\hline Visualisasi permasalahan & 3,80 & Baik \\
Mendeskripsikan masalah & 3,76 & Baik \\
kedalam konsep fisika & & \\
Merencanakan solusi & 3,82 & Baik \\
Melaksanakan rencana & 3,85 & Baik \\
Mengevaluasi solusi & 3,96 & Baik \\
Rata-rata & $\mathbf{3 , 8 8}$ & Baik
\end{tabular}

Tabel 3 menunjukkan skor persepsi siswa pada indikator visualisasi permasalahan $\left(\mathrm{I}_{1}\right)$ dan mendeskripsikan masalah kedalam konsep fisika $\left(\mathrm{I}_{2}\right)$ yang didapat berada pada kategori baik dengan rata-rata skor masing-masing 3,80 dan 3,76. Dilihat dari hasil data angket bahwa guru telah membekali keterampilan abad 21 pada aspek pemecahan masalah dengan mengajarkan siswa mengubah bentuk visual kedalam deskripsi fisika dan mengidentifikasi masalah berdasarkan konsep dasar fisika yang terkait. Persepsi siswa terhadap kemampuan merencanakan solusi $\left(\mathrm{I}_{3}\right)$ berada pada kategori baik dengan skor rata-rata 3,82. Berdasarkan hasil data angket guru sudah mengajarkan siswa menentukan prinsip fisika yang mendasari permasalahan dan menentukan persamaan yang tepat untuk memecahkan masalah.

Indikator melaksanakan rencana $\left(\mathrm{I}_{4}\right)$ berada pada kategori baik yaitu dengan skor rata-rata 3,85. Berdasarkan hasil data angket guru telah mengajarkan siswa mensubstitusikan nilai besaran yang diketahui ke persamaan dan melakukan perhitungan dengan menggunakan persamaan yang dipilih. Indikator mengevaluasi solusi $\left(\mathrm{I}_{5}\right)$ diperoleh skor rata-rata 3,96 yang tergolong pada kategori baik. Hasil data angket menunjukan bahwa guru telah mengajarkan siswa mengevaluasi kesesuaian permasalahan yang diselesaikan dengan konsep fisika yang digunakan, mengevaluasi ketetapan satuan dan mengevaluasi rasionalitas jawaban atau solusi yang dihasilkan.

\subsection{Angket Persepsi Guru terhadap Pembekalan Keterampilan Pemecahan Masalah yang} Telah Dilakukan

Sasaran dari angket ini adalah untuk guru mata pelajaran fisika dikelas siswa yang telah diberikan angket dengan indikator yang sama dan pernyataannya disesuaikan. Berikut hasil angket tersebut.

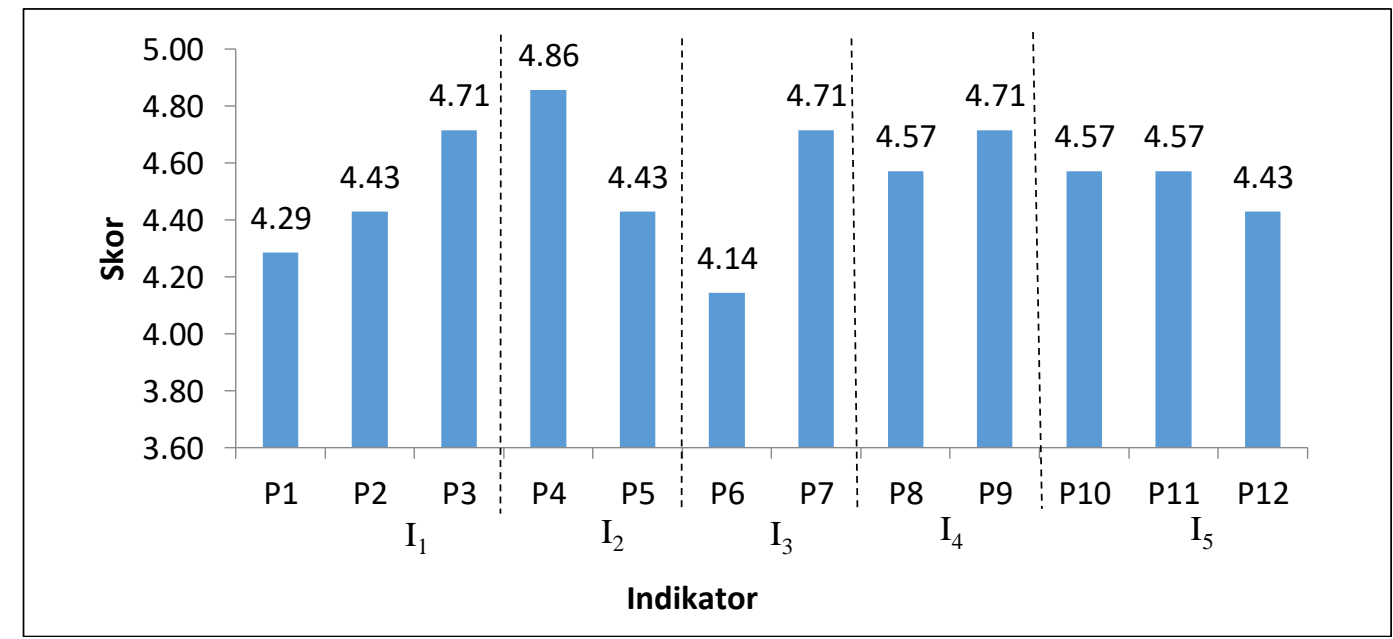

Gambar 3. Persepsi Guru terhadap Pembekalan Keterampilan Pemecahan Masalah

Berdasarkan gambar 3 diketahui bahwa hasil analisis data angket menunjukkan skor di atas 4 dengan kategori Baik. Adapun skor rata-rata setiap indikator pembekalan keterampilan pemecahan masalah oleh guru dapat dilihat pada tabel 4. 
Table 4. Persepsi Guru Terhadap Pembekalan Keterampilan Pemecahan Masalah

\begin{tabular}{lcc}
\hline \multicolumn{1}{c}{ Indikator keterampilan } & Skor rata-rata & Kategori \\
\hline Visualisasi permasalahan & 4,47 & Baik \\
Mendeskripsikan masalah & 4,64 & Bak \\
kedalam konsep fisika & & \\
Merencanakan solusi & 4,47 & Baik \\
Melaksanakan rencana & 4,64 & Baik \\
Mengevaluasi solusi & 4.5 & Baik \\
Rata-rata & $\mathbf{4 , 5 4}$ & Baik \\
\hline
\end{tabular}

Berdasarkan tabel 4 dapat dilihat bahwa indikator visualisasi permasalahan memiliki $\left(\mathrm{I}_{1}\right)$ nilai skor rata-rata 4,47 yang berada pada kategori baik. Berdasarkan hasil data angket persepsi guru terhadap pembekalan keterampilan abad 21 pada aspek pemecahan masalah menunjukan bahwa guru telah membekali siswa dalam hal memvisualisasi suatu masalah kedalam bentuk sketsa, gambar diagram atau bentuk representasi lain yang sesuai, menuliskan simbol-simbol fisika yang mempresentasikan variabel atau besaran yang terlibat dalam permasalahan dan menentukan besaran-besaran yang diketahui dan besaran yang ditanyakan dalam pemasalahan.

Skor persepsi siswa pada indikator mendeskripsikan masalah kedalam konsep fisika $\left(\mathrm{I}_{2}\right)$ yang didapat adalah 4,64 yang berada pada kategori baik. Dilihat dari hasil data angket bahwa guru telah membekali dengan mengajarkan siswa mengubah bentuk visual kedalam deskripsi fisika dan mengidentifikasi masalah berdasarkan konsep dasar fisika yang terkait. Persepsi siswa terhadap kemampuan merencanakan solusi $\left(\mathrm{I}_{3}\right)$ berada pada kategori baik dengan skor rata-rata 4,47. Berdasarkan hasil data angket guru sudah mengajarkan siswa menentukan prinsip fisika yang mendasari permasalahan dan menentukan persamaan yang tepat untuk memecahkan masalah.

Indikator melaksanakan rencana $\left(\mathrm{I}_{4}\right)$ berada pada kategori baik yaitu dengan skor rata-rata 4,64. Berdasarkan hasil data angket guru telah mengajarkan siswa mensubstitusikan nilai besaran yang diketahui ke persamaan dan melakukan perhitungan dengan menggunakan persamaan yang dipilih. Indikator mengevaluasi $\left(\mathrm{I}_{5}\right)$ solusi diperoleh skor rata-rata 4,5 yang tergolong pada kategori baik. Hasil data angket menunjukan bahwa guru telah mengajarkan siswa mengevaluasi kesesuaian permasalahan yang diselesaikan dengan konsep fisika yang digunakan, mengevaluasi ketetapan satuan dan mengevaluasi rasionalitas jawaban atau solusi yang dihasilkan.

\subsection{Angket Persepsi Siswa terhadap Penguasaan Keterampilan Pemecahan Masalah yang Dimiliki Siswa}

Angket ini digunakan untuk mengetahui persepsi siswa mengenai penguasaan keterampilan pemecahan masalah yang dimilikinya. Angket ini memiliki indikator yang sama dengan angketangket sebelumnya namun pernyataan setiap butirnya disesuaikan. Berikut hasil angket tersebut.

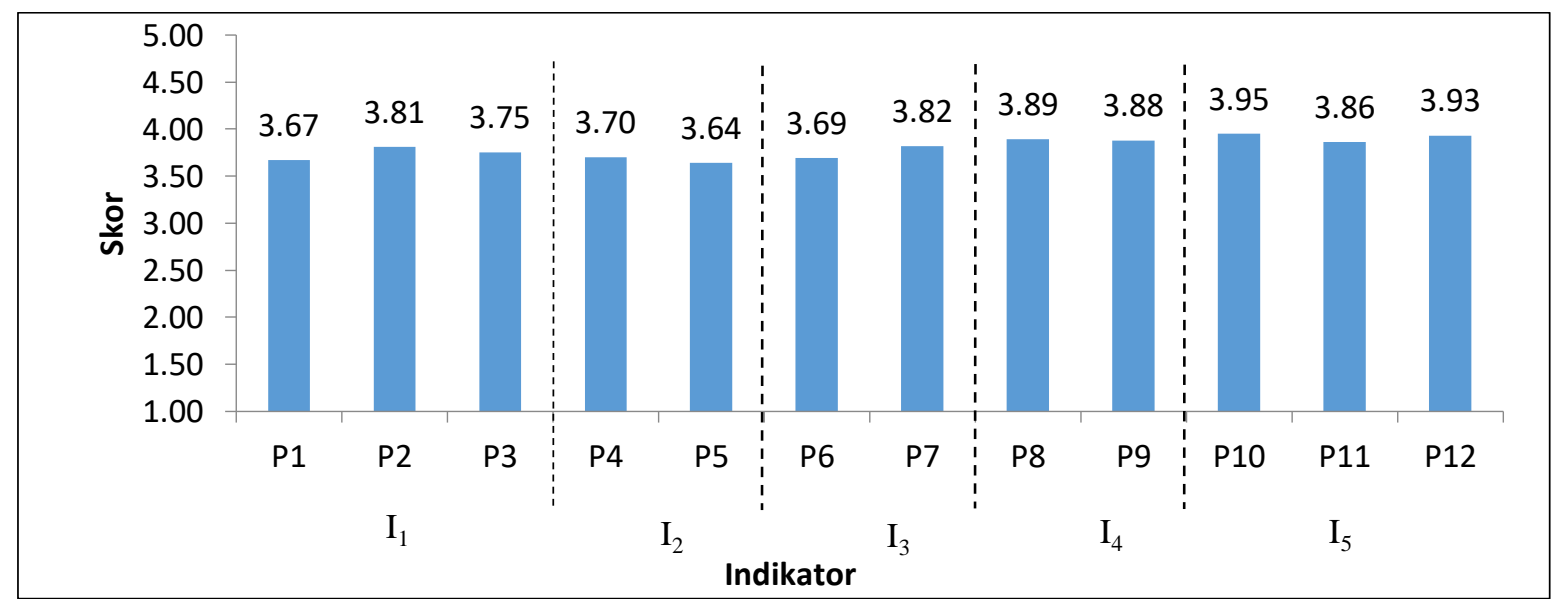

Gambar 4. Persepsi Siswa terhadap Penguasaan Keterampilan Pemecahan Masalah

Berdasarkan gambar 4, penguasaan siswa terhadap keterampilan pemecahan masalah menurut persepsi siswa hasil analisis data angket skor rata-rata setiap indikator dan kategori penguasaan keterampilan pemecahan masalah siswa dapat dilihat pada tabel 5.

Identifikasi Pembekalan Keterampilan Abad 21 pada Aspek Keterampilan Pemecahan Masalah Siswa SMA Kota Bengkulu dalam.... Agung Jayadi, Desy Hanisa Putri, Henny Johan 


\section{Tabel 5. Persepsi Siswa Terhadap Penguasaan Keterampilan Pemecahan Masalah}

\begin{tabular}{lcc}
\hline \multicolumn{1}{c}{ Indikator keterampilan } & Skor rata-rata & Kategori \\
\hline Visualisasi permasalahan & 3,74 & Baik \\
Mendeskripsikan masalah & 3,67 & Baik \\
kedalam konsep fisika & & \\
Merencanakan solusi & 3,75 & Baik \\
Melaksanakan rencana & 3,88 & Baik \\
Mengevaluasi solusi & 3,91 & Baik \\
Rata- rata & $\mathbf{3 , 7 9}$ & Baik \\
\hline
\end{tabular}

Tabel 5 menunjukkan bahwa indikator visualisasi permasalahan $\left(\mathrm{I}_{1}\right)$ memiliki nilai skor ratarata 3,75 yang berada pada kategori baik. Berdasarkan hasil data angket siswa mampu memvisualisasi suatu masalah kedalam bentuk sketsa, gambar diagram atau bentuk representasi lain yang sesuai, menuliskan simbol-simbol fisika yang mempresentasikan variabel atau besaran yang terlibat dalam permasalahan dan mampu menentukan besaran-besaran yang diketahui dan besaran yang ditanyakan dalam pemasalahan. Skor persepsi siswa pada indikator mendeskripsikan $\left(\mathrm{I}_{2}\right)$ masalah kedalam konsep fisika yang didapat adalah 3,67 yang berada pada kategori baik. Dilihat dari hasil data angket siswa mampu mengubah bentuk visual kedalam deskripsi fisika dan mampu mengidentifikasi masalah berdasarkan konsep dasar fisika yang terkait.

Persepsi siswa terhadap kemampuan merencanakan solusi $\left(\mathrm{I}_{3}\right)$ berada pada kategori baik dengan skor rata-rata 3,75. Berdasarkan hasil data angket siswa sudah mampu menentukan prinsip fisika yang mendasari permasalahan dan mampu menentukan persamaan yang tepat untuk memecahkan masalah. Indikator melaksanakan rencana $\left(\mathrm{I}_{4}\right)$ berada pada kategori baik yaitu dengan skor rata-rata 3,88. Berdasarkan hasil data angket siswa mampu mensubstitusikan nilai besaran yang diketahui ke persamaan dan mampu melakukan perhitungan dengan menggunakan persamaan yang dipilih. Indikator mengevaluasi solusi diperoleh skor rata-rata 3,91 yang tergolong pada kategori baik. Hasil data angket menunjukan bahwa siswa telah mampu mengevaluasi kesesuaian permasalahan yang diselesaikan dengan konsep fisika yang digunakan, mampu mengevaluasi ketetapan satuan dan mampu mengevaluasi rasionalitas jawaban atau solusi yang dihasilkan. Dari tabel 5 dapat diketahui bahwa rata-rata dari setiap indikator keterampilan pemecahan masalah adalah 3,79 yang termasuk kedalam kategori baik sehingga didapatkan bahwa penguasaan dan pembekalan keterampilan abad 21 pada aspek pemecahan masalah berada pada kategori baik.

Berdasarkan penjelasan di atas kita dapat ketahui bahwasannya hasil rata-rata jawaban siswa terhadap angket penguasaan dan pembekalan keterampilan abad 21 aspek pemecahan masalah bervariasi pada setiap butir pernyataan yang merupakan sub indikator dari kelima indikator pemecahan masalah. Hasil yang tinggi menunjukkan bahwa siswa telah menguasai dan telah dibekali indikator pemecahan masalah tersebut. Jika hasil lebih rendah, hal ini menunjukkan bahwa kemampuan siswa pada sub indikator tersebut masih dibawah kemampuan indikator keterampilan yang lainnya. Hasil terendah pada penelitian ini yaitu pada kemampuan mengidentifikasi masalah berdasarkan konsep dasar fisika, yang berarti kemampuan ini yang harus lebih di tingkatkan agar penguasaan keterampilan pemecahan masalah siswa menjadi lebih baik. Hal ini bisa dilakukan dengan cara guru membekali siswa akan keterampilan tersebut.

Secara keseluruhan, pembekalan keterampilan abad 21 pada aspek keterampilan pemecahan masalah berdasarkan hasil rata-rata setiap butir dari kedua angket berada pada kategori baik menurut persepsi guru dan siswa. Artinya siswa SMA Negeri Kota Bengkulu telah dibekali dengan keterampilan pemecahan masalah sehingga hasil yang didapatkan pada angket ketiga yakni penguasaan keterampilan pemecahan masalah berada pada kategori baik. Hal ini sejalan dengan hasil penelitian lain yang menyimpulkan bahwa pembekalan keterampilan abad 21 pada pembelajaran fisika SMA di Provinsi Bengkulu dalam kategori cukup baik [5]. Demikian juga penelitian lain di SMK Negeri Solok yang menyatakan bahwa pembekalan keterampilan abad 21 yang dilakukan oleh guru di sekolah tersebut dalam kategori baik [9]. Keterampilan pemecahan masalah merupakan salah satu keterampilan yang harus dibekalkan pada siswa di abad 21 ini untuk 
kehidupannya di masa mendatang. Seseorang tidak memiliki keterampilan ini sejak lahir melainkan keterampilan ini diperoleh dari proses latihan, belajar, atau pengalaman [10].

\section{UCAPAN TERIMA KASIH}

Penulis mengucapkan terima kasih kepada dosen yang telah membimbing dalam penulisan artikel ini. Terima kasih kepada siswa dan guru SMAN Kota Bengkulu yang telah menjadi bagian dari proses penelitian dan pihak lain yang telah membantu.

\section{DAFTAR PUSTAKA}

[1]Wijaya, E. Y., Sudjimat, D. A., dan Nyoto, A., 2016, Transformasi Pendidikan Abad 21 Sebagai Tuntutan Transformasi Pendidikan Abad 21 Sebagai Tuntutan, Prosiding Seminar Nasional Pendidikan Matematika 2016, Vol. 1, hal. 263-278.

[2]Badan Standar Nasional Pendidikan (BSNP), 2010, Paradigma Pendidikan Nasional Abad XXI Versi 1, BNSP: Jakarta.

[3]Abidin, 2014, Desain Sistem Pembelajaran dalam Konteks Kurikulum 2013, Refika Aditama, Bandung.

[4]Trilling, B., dan Fadel, C., 2009,. 21st Century Skills: Learning Fos Life in Our Times, San Fransisco, Calif:Jossey-Bass/Jhon Wiley \& Sons.

[5] Putri, D. H., Risdianto, E.., dan Sutarno, 2017, Identifikasi Keterlaksanaan Praktikum Fisika SMA dan Pembekalan Keterampilan Abad 21, SEMNAS SAINS \& ENTERPRENEURSHIP $I V$, Bengkulu.

[6]Zubaidah, S., 2016, Keterampilan Abad Ke-21: Keterampilan Yang Diajarkan, Seminar Nasional Pendidikan STKIP Sintang, hal. 1-17.

[7]Heller, P,. Keith, P., dan Anderson, S., 1992, Teaching problem solving through cooperative grouping : part 1: group versus individual problem solving, Amercian Journal of Physics, No. 7, Vol. 60, hal. 627-636.

[8]Sugiyono, 2010, Metode Penelitian \& Pengembangan, ALFABETA, Bandung.

[9] Yulianisa, Rizal, F., Oktaviani, dan Abdullah, R., 2018, Tinjauan Keterampilan Abad 21 (21 ${ }^{\text {st }}$ Century Skills) di Kalangan Guru Kejuruan (Studi Kasus : SMK Negeri 2 Solok), CIVED, No. 3, Vol. 5, hal. 1-8.

[10] Redhana, I W., 2019, Mengembangkan Keterampilan Abad ke-21 dalam Pembelajaran Kimia, Jurnal Inovasi Pendidikan Kimia, No 1, Vol 13, 2019, hal. 2239 - 2253. 